\title{
PENGANGKATAN ANAK ADOPSI DALAM TINJAUAN HUKUM ISLAM \& SISTEM HUKUM DI INDONESIA
}

Nuzha

Sekolah Tinggi Agama Islam Negeri Majene

Email : nuzha@stainmajene.ac.id

\begin{abstract}
ABSTRAK
Rumah tangga yang tidak mempunyai anak akan tidak sempurna keberadaannya. Demi memperoleh anak berbagai cara dilakukan seperti mengadopsi/mengangkat anak orang lain, baik dari anak keluarga maupun dari orang lain untuk dijadikan anak kandung Pada masyarakat umum masih banyak yang belum mengetahui tata cara pengangkatan anak yang benar. Pengangkatan anak/adopsi akan berdampak negatif pada keturunan, warisan dan sebagainya, misalnya menghapus nasab anak yang diangkat dengan orang tua kandungnya, memberikan warisan kepada anak angkat padahal ada ahli waris lain yang berhak terhadap harta tersebut dan lain-lain yang bertentangan dengan ajaran Islam dan sistem hukum yang berlaku di Indonesia.
\end{abstract}

Kata Kunci : Anak Adopsi, Hukum Islam, Sistem Hukum Indonesia

\section{A. PENDAhuluan}

Secara naluri insani, setiap pasangan suami istri berkeinginan untuk mempunyai anak untuk menyambung keturunan, mewarisi serta menjadi hiburan. Sebuah rumah tangga yang tidak mempunyai anak akan terasa gersang dan terasa tidak sempurna keberadaannya, meskipun ada keluarga lain yang ikut serta dalam keluarga tersebu. Namun, tidak semua keinginan manusia dapat terwujud karena takdir Allah yang menentukan segala sesuatu. Akad pernikahan terjadi sudah berlangsung lama namun buah hati/anak yang diharapkan tak kunjung datang. Hal tersebut terjadi kemungkinan karena salah satu atau kedua pasangan suami istri mandul, sakit, cacat dan lain-lain. 
Demi memperoleh anak berbagai cara dilakukan seperti mengadopsi / mengangkat anak orang lain, baik dari anak keluarga maupun dari orang lain untuk dijadikan anak kandung yang mengambil nasab, mewarisi harta peninggalan setelah orang tua angkat meninggal dan lain-lain. ${ }^{1}$

Namun, pada masyarakat umum khususnya umat Islam masih banyak yang belum mengetahui tata cara pengangkatan anak yang sesuai syariat Islam sehingga berdampak negatif pada keturunan, warisan dan sebagainya.

\section{B. PEMBAHASAN}

\section{Konsep Pengangkatan Anak/Adopsi}

Menurut etimologi, pengangkatan anak dalam Bahasa Indonesia disebut dengan adopsi, yang berasal dari Bahasa Belanda “Adoptie” atau “Adoption” (Bahasa Inggris). Menurut Bahasa Arab disebut "Tabanni” yang menurut Prof. Mahmud Yunus diartikan dengan mengambil anak angkat sedangkan menurut Kamus Munjid diartikan "menjadikannya sebagai anak". Pengertian dalam Bahasa Belanda menurut kamus hukum berarti pengangkatan anak untuk sebagai anak kandungnya sendiri. ${ }^{2}$

Menurut terminologi dalam Ensiklopedia Umum dijelaskan bahwa adopsi merupakan suatu cara untuk mengadakan hubungan antara orang tua dan anak yang diatur dalam peraturan perundang-undangan. Biasanya adopsi dilaksanakan untuk mendapatkan pewaris atau untuk mendapatkan anak bagi orang tua yang tidak mempunyai anak. Konsekuensi dari adopsi tersebut yaitu anak yang di adopsi memiliki status sebagai anak kandung yang sah dengan segala hak dan kewajiban. Calon orang tua harus memenuhi syarat-syarat untuk dapat menjamin kesejahteraan anak sebelum melakukan adopsi. ${ }^{3}$

Menurut Prof. R. Soepomo, adopsi adalah mengangkat anak orang lain sebagai anak sendiri. Menurut Dr. J. A Nota, seorang ahli hukum Belanda adopsi adalah suatu lembaga hukum yang dapat memindahkan seseorang ke dalam ikatan keluarga lain (baru) sedemikian

\footnotetext{
${ }^{1}$ Abdul Wahab Abd. Muhaimin, Kajian Islam Aktual (Cet. I; Jakarta: Gaung Persada Press), h. 143.

${ }^{2}$ Muderis Zaini, Adopsi (Suatu Tinjauan Dari Tiga Sistem Hukum) (Cet. IV; Jakarta: Sinar Grafika, 2002), h. 174.

${ }^{3}$ Muderis Zaini, Adopsi (Suatu Tinjauan Dari Tiga Sistem Hukum) (Cet. IV; Jakarta: Sinar Grafika, 2002), h. 175.
} 
rupa sehingga meninggalkan secara keseluruhan atau sebagian hubungan hukum yang sama seperti antara seorang anak yang dilahirkan sah dengan orang tuanya. ${ }^{4}$

Dr. Mahmud Syaltut membedakan dua macam arti anak angkat, yaitu:

a. Penyatuan seorang anak yang diketahui sebagai anak orang lain ke dalam keluarga. Anak tersebut diperlakukan sebagai anak dalam segi kecintaan, pemberian nafkah, pendidikan dan pelayanan dalam segala kebutuhannya, dan tidak dinasabkan pada orang tua angkat.

b. Berasal dari kata "tabanni" (mengangkat anak secara mutlak) menurut syariat adat kebiasaan yang berlaku pada manusia. Tabanni ialah memasukkan anak yang diketahui sebagai orang lain ke dalam keluarga yang tidak ada hubungan nasab kepada orang tua angkat sebagai anak yang sah tetapi mempunyai hak dan ketentuan hukum sebagai anak..$^{5}$

Beberapa pengertian tersebut dapat disimpulkan bahwa mengenai adopsi belum ada persamaan atau kesatuan arti. Namun, secara garis besar adposi dapat dibagi ke dalam dua pengertian, yaitu:

a. Adopsi dalam arti luas yakni pengangkatan anak/ adopsi orang lain sedemikian rupa sehingga antara anak yang diangkat dengan orang tua angkat timbul hubungan antara anak angkat sebagai anak kandung dan orang tua angkat kandung.

b. Adopsi dalam arti terbatas yakni pengangkatan anak/ adopsi orang lain yang memiliki hubungan terbatas pada hubungan sosial yaitu sebagai anak angkat dan orang tua angkat.

Sejak zaman dahulu, adopsi telah dilakukan dengan cara dan motivasi yang berbedabeda, sejalan dengan sistem hukum dan perasaan hukum yang hidup serta berkembang di dalam masyarakat yang bersangkutan. Di Indonesia, adopsi sudah dilakukan sejak zaman dahulu. ${ }^{6}$

Tujuan dari adopsi bermacam-macam, yaitu:

a. Tidak mempunyai keturunan.

${ }^{4}$ Djaja S. Meliala, Pengangkatan Anak (Adopsi) di Indonesia (Bandung: Tarsito, 1982), h. 3.

${ }^{5}$ Mahmud Syaltut, Al-Fatawa (Mesir: Dar al-Syuruq, 1980), h. 359.

${ }^{6}$ Amir Martosedono, Tanya Jawab Pengangkatan Anak \& Masalahanya (Semarang: Dahara Prize, 1997), h. 14. 
b. Belas kasihan kepada anak karena orang tua kandung anak tersebut tidak mampu memberikan nafkah kepada anaknya.

c. Belas kasihan, karena anak tersebut yatim piatu.

d. Belas kasihan karena anak tidak terurus.

e. Hanya mempunyai anak laki-laki maka mengadopsi anak perempuan atau sebaliknya.

f. Sebagai "pancingan" yakni dengan mengadopsi anak keluarga tersebut akan dikaruniai anak kandung.

g. Menambah tenaga dalam keluarga.

h. Memberikan pendidikan yang layak bagi anak.

i. Unsur kepercayaan.

j. Menyambung keturunan dan mendapatkan generasi bagi yang tidak mempunyai anak kandung.

k. Adanya hubungan keluarga. Orang tua yang tidak mempunyai anak biasanya meminta anak dari keluarga yang lain supaya dijadikan anak angkat.

1. Anak angkat diharapkan dapat menolong di hari tua. Misalnya, mengangkat anak laki-laki agar dapat mengkremasi jenazah orang tua serta untuk memelihara abunya.

m. Mempererat hubungan kekeluargaan.

n. Dahulu anak sering sakit atau meninggal maka anak yang baru lahir diserahkan kepada keluarga atau orang tua lain untuk dijadikan anak angkat, dengan harapan anak yang bersangkutan selalu sehat dan panjang umur. ${ }^{7}$

Ada dua macam anak angkat, yaitu:

a. Seseorang yang memelihara anak orang lain yang kurang mampu untuk di didik dan disekolahkan pada pendidikan formal, sehingga anak tersebut akan menjadi anak yang berpendidikan. Anak dan orang tua tersebut tidak memiliki hubungan nasab. Namun, dapat saling wasiat mewasiatkan harta apabila salah satunya meninggal dunia.

b. Mengangkat anak menurut adat kebiasaan yang disebut tabanni atau adopsi, yakni anak tersebut dimasukkan dalam keluarga yang mengangkat sebagai anak kandung, sehingga mempunyai kedudukan ahli waris.

${ }^{7}$ Muderis Zaini, Adopsi (Suatu Tinjauan Dari Tiga Sistem Hukum) (Cet. IV; Jakarta: Sinar Grafika, 2002), h. 5. 
Menurut Kitab Undang-undang Hukum Perdata (Burgelijk Wetboek) tidak ditemukan suatu ketentuan yang mengatur masalah adopsi atau anak angkat. BW hanya mengatur tentang pengakuan anak yang lahir diluar perkawinan, yaitu seperti yang diatur dalam Buku I Bab XII Bagian Ketiga BW Pasal 280-289 yang mengatur tentang pengakuan terhadap anak-anak yang lahir diluar perkawinan.

Lembaga pengakuan anak yang lahir diluar perkawinan tidak sama dengan lembaga pengangkatan anak. Dilihat dari segi orang yang berkepentingan, pengakuan anak yang lahir diluar perkawinan hanya dapat dilakukan oleh laki-laki saja yaitu, ayah biologis dari anak yang akan diakui bukan dari ibu biologis, sedangkan pada lembaga pengangkatan anak tidak terbatas pada ayah biologis tetapi orang tua perempuan atau laki-laki lain yang sama sekali tidak ada hubungan biologis dengan anak itu dapat melakukan permohonan pengangkatan anak sepanjang memenuhi persyaratan hukum. ${ }^{8}$

Mengingat kebutuhan masyarakat tentang pengangkatan anak menunjukkan angka yang meningkat, maka pemerintah kolonial Hindia Belanda pada Tahun 1917 mengeluarkan Staatsblad No. 129 Pasal 5-15 yang isinya mengatur secara khusus tentang pengangkatan anak tersebut guna melengkapi Hukum Perdata Barat (BW).

Pengangkatan anak dilakukan berdasarkan adat kebiasaan setempat dan berdasarkan peraturan perundang-undangan. Berdasarkan adat kebiasaan artinya pengangkatan anak dilakukan dalam satu komunitas yang masih melakukan adat dan kebiasaan dalam kehidupan bermasyarakat.

\section{Pengangkatan Anak/Adopsi dalam Hukum Islam}

Pengangkatan anak telah banyak ditemui di kalangan bangsa Arab bahkan sebelum Islam datang. Pengangkatan anak tersebut diartikan sebagai pengangkatan anak orang lain dengan status anak kandung. Menurut sejarah, Nabi Muhammad SAW sebelum menerima kerasulan mempunyai seorang anak angkat bernama Zaid bin Haritsah dalam status budak hadiah dari Khadijah binti Khuwailid. ${ }^{9}$

Pengangkatan anak dalam hukum Islam terdapat dalam QS. al-Ahzab/22: 4-5

${ }^{8}$ Soedharyo Soimin, Hukum Orang \& Keluarga (Cet. III; Jakarta: Sinar Grafika, 2010), h. 35.

${ }^{9}$ Abdul Wahab Abd. Muhaimin, Kajian Islam Aktual (Cet. I; Jakarta: Gaung Persada Press), h. 144. 


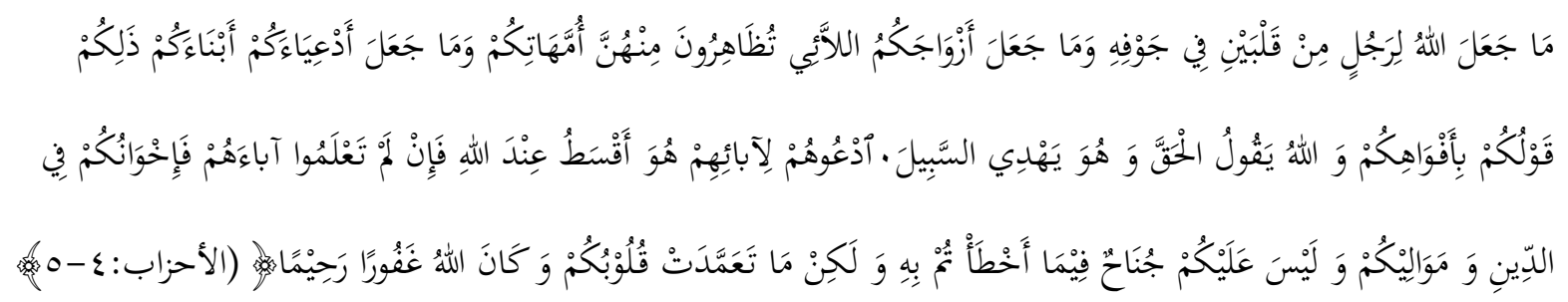

Terjemahnya:

Tidaklah Allah menjadikan pada seseorang dua hati dalam rongganya dan tidaklah isteriisteri kamu yang telah kamu serupakan punggungnya dari kalangan mereka menjadi ibumu dan tidaklah Dia menjadikan anak yang kamu angkat jadi anakmu, benar-benar itu hanyalah ucapanmu dengan mulutmu. Dan Allah mengatakan yang benar dan Dia akan menunjukkan jalan.

Panggillah mereka dengan nama bapak-bapak mereka. Itulah yang lebih adil disisi Allah. Dan jika tidak kamu ketahui siapa bapak-bapak mereka, maka mereka adalah saudara kamu seagama maula-maula kamu. Tetapi tidaklah kamu berdosa jika kamu salah dengan dia, melainkan jika disengaja oleh hati kamu dan Allah adalah Maha Pengampun, Maha Penyayang. ${ }^{10}$

As-Suyuti meriwayatkan dari Mujahid r.a. bahwa Nabi SAW memerdekakan Zaid bin Haritsah dan mengangkatnya sebagai anak. Peristiwa tersebut terjadi sebelum kerasulan beliau. Ketika Nabi mengawini Zainab binti Jahsy, mantan istri Zaid, orang-orang Yahudi berkata: "Muhammad kawin dengan istri anaknya, padahal melarang manusia berbuat yang demikian itu." Maka turunlah ayat tersebut.

Ahli Tafsir sepakat bahwa ayat tersebut juga turun berkaitan dengan Zaid bin Haritsah. Para Imam sepakat dari riwayat bahwa Ibnu Umar: "Kami dulu tidak pernah memanggil Zaid bin Haritsah tetapi memanggil Zaid bin Muhammad. Sebagaimana yang diriwayatkan oleh Anas bin Malik, bahwa Zaid adalah tawanan dari Syam yang diseret para penunggang kuda dari Tihamah dan dibeli oleh hakim bin Hizam bin Khuwailid untuk dihadiahkan kepada 419.

\footnotetext{
${ }^{10}$ Departemen Agama RI, Al-Qur'an dan Terjemahnya (Jakarta: CV. Pustaka Agung Harapan, 2006), h.
} 
bibinya yaitu Khadijah binti Khuwailid dan dihadiahkan kepada Nabi SAW. Kemudian, beliau memerdekakan dan mengangkatnya sebagai anak. Zaid tinggal bersama Nabi dalam beberapa waktu sampai bapak dan pamannya datang untuk menebusnya. Pada saat bapak dan pamannya datang, Nabi berkata kepada keduanya: "Silahkan berikan pilihan kepada Zaid jika dia memilih kalian maka ia menjadi milik kalian tanpa tebusan.” Zaid lebih memilih bersama Nabi dari pada kemerdekaan. Nabi bersabda: "Wahai segenap orang Quraisy, "Saksikanlah ini anakku yang aku mewarisinya dan dia mewarisiku.” Lalu, Zaid berkeliling di sekitar orang Quraisy dan menyaksikan kejadian tersebut. Bapak dan pamannya juga menerima dan kembali ke kampung halaman mereka.

Ayat selanjutnya menjelaskan bahwa Ibnu Umar tidak pernah memanggil Zaid bin Haritsah tetapi Zaid bin Muhammad. Hal tersebut membuktikan bahwa perilaku mengangkat anak sudah berlangsung sejak zaman Jahiliyah sampai pada masa perkembangan awal Islam. Hubungan tersebut terdapat hak waris antar orang tua angkat dan anak angkat. Kemudian, Allah menghapus hukum mengangkat anak dan melarang secara mutlak dengan memberikan petunjuk bahwa yang terbaik dan adil adalah menasabkan seorang anak kepada ayah kandung bukan kepada ayah angkat. ${ }^{11}$

Kedua ayat tersebut menerangkan bahwa:

1. Pengangkatan anak dalam tradisi zaman jahiliyah yang memberi status kepada anak angkat sama dengan anak kandung tidak dibenarkan oleh Islam.

2. Hubungan antara anak angkat dengan orang tua yang mengangkat dan keluarga anak yang diangkat tetap seperti sebelum pengangkatan yaitu, tidak mempengaruhi kemahraman dan kewarisan baik dari kerabat maupun diluar lingkungan kerabat.

Maka dapat dipahami bahwa pengangkatan anak/adopsi yang dilarang, yaitu pengangkatan anak sebagai anak kandung dalam segala hal. Hal tersebut banyak terjadi di beberapa daerah di Indonesia yang menghilangkan atau memutuskan kedudukan anak angkat dengan orang tua kandung yang dapat merubah ketentuan mengenai waris.

Berdasarkan kedua ayat tersebut sangat jelas bahwa agama Islam melarang mengangkat anak orang lain menjadi anak kandung dalam segala hal. Setelah terjadi peristiwa

\footnotetext{
${ }^{11}$ Mohammad Fuad Fachrudin, Masalah Anak Dalam Hukum Islam (Jakarta: CV. Pedoman Ilmu Jaya, 1993), h. 8.
} 
Rasulullah mengangkat Zaid bin Haristah menjadi anak, maka tidak ada lagi tempat untuk mengangkat anak sebagai anak kandung di dalam syariat Islam. ${ }^{12}$

Islam dengan tegas mengharamkan perbuatan tersebut karena:

1. Mengangkat anak adalah suatu kebohongan di hadapan Allah dan masyarakat yang hanya merupakan kata-kata yang diucapkan berulang kali tetapi tidak akan menimbulkan kasih sayang yang sebenarnya, seperti yang timbul di kalangan ayah, ibu dan keluarga sebenarnya dan hanya mencampur-adukkan keturunan yang kelak menyebabkan hilangnya kebenaran dan runtuhnya ikatan keluarga yang sebenarnya.

2. Mengangkat anak sering dijadikan sebagai suatu cara untuk menipu dan menyusahkan kaum keluarga. Misalnya, seorang mengangkat anak yang akan menjadi pewaris dari harta kekayaannya sehingga tidak memberikan warisan kepada ahli waris lain yang mempunyai hak dalam harta tersebut sesuai ketentuan Allah.

3. Mengangkat anak dan menetapkan status sama dengan anak kandung, terkadang menjadi beban dan tugas yang berat bagi keluarga ayah angkat. Apabila ayah angkat meninggal dunia maka keluarganya bertugas untuk memberi nafkah. Hal tersebut menyebabkan pelimpahan tugas-tugas kepada keluarga yang sama sekali tidak ada hubungan darah dengan anak angkat.

4. Mengharamkan yang halal atau menghalalkan yang haram karena anak tersebut menjadi muhrim dari wanita-wanita dari keluarga yang bukan muhrimnya, sehingga boleh melihat aurat yang asalnya tidak boleh dilihat atau menyebabkan tidak boleh menikah dengan wanita-wanita yang sebenarnya halal untuk dinikahi.

5. Masalah perwalian, dalam pernikahan jika anak angkat tersebut perempuan, maka yang menjadi wali adalah ayah angkat padahal yang wajib menjadi wali yaitu ayah kandung dan menurut urutan nasab. Apabila semua wali tidak ada atau terjadi perselisihan antara wali maka perwalian diserahkan kepada wali hakim.

Syariat Islam yang ditegakkan diatas kebenaran dan kejujuran untuk membina masyarakat dengan landasan hubungan yang murni dan wajar dalam mengatur susunan keluarga melarang pengangkatan anak yang diperlakukan seperti anak kandung.

\footnotetext{
${ }^{12}$ Abdul Wahab Abd. Muhaimin, Kajian Islam Aktual (Cet. I; Jakarta: Gaung Persada Press), h. 149.
} 
Agama Islam membatalkan dan tidak mengakui adat-istiadat dalam pengangkatan anak orang lain untuk dijadikan sebagai anak kandung karena akan berdampak negatif.

Hadis yang berhubungan dengan anak angkat, yaitu:

$$
\text { لا كن أ بى ذر ر رض الله عنه أنه سمع رسلو الله سلى الله عليه و سلم يقول: ليس من رجل اد عى لغير أبيه, وهو يعلمه ا }
$$

Artinya:

Dari Abu Dzar ra, bahwasanya ia mendengar Rasulullah SAW bersabda: "Tidak seorang pun yang mengikuti (membanggakan diri) kepada bukan ayah yang sebenarnya, sedang ia mengetahui bahwa itu bukan ayahnya, melainkan ia telah kufur. Dan barang siapa yang mengakui sesuatu yang tidak ada padanya, maka ia bukan dari kalangan kami (kalangan kaum muslim) dan hendaklah dia menyiapkan diri sendiri tempatnya dalam api neraka”. (HR. Muslim)

Kesimpulan hadits tersebut bahwa haram hukumnya membanggakan diri kepada orang lain yang bukan ayah kandung maka haram mengangkat anak orang lain dan membangsakannya/menyandarkan nasabnya kepada orang yang mengangkatnya sebagai anak kandung, tetapi boleh mengangkatnya sebagai anak asuh karena tidak menyandarkan nasab anak asuh tersebut kepada nasab orang tua angkat. Hal tersebut justru dianjurkan oleh agama agar anak orang miskin tersebut tidak terlantar.

Inti dari pengangkatan anak menurut hukum Islam adalah mubah. Hukumnya bisa berubah menjadi sunnah atau haram sesuai dengan situasi dan kondisi. ${ }^{13}$

Seiring perkembangan zaman maka hukum Islam pun selalu berkembang, termasuk dalam hal pengangkatan anak di Indonesia. Hal tersebut terlihat dari hasil rumusan Tim Pengkajian Bidang Hukum Islam pada Pembinaan Hukum Nasional dalam Seminar Pengkajian Hukum 1980/1981 di Jakarta yang pernah mengusulkan pokok-pokok pikiran

\footnotetext{
${ }^{13}$ Chuzaimah T. Yanggo, Problematika Hukum Islam Kontemporer (Jakarta: Pustaka Firdaus, 1994), h. 132.
} 
sebagai bahan penyusunan Rancangan Undang-undang tentang anak angkat yang dipandang dari sudut hukum Islam. Pokok-pokok pikiran tersebut adalah:

1. Hukum Islam tidak melarang adanya lembaga adopsi bahkan membenarkan dan menganjurkan demi untuk kesejahteraan anak dan kebahagiaan orang tua.

2. Perlu diadakan peraturan perundang-perundangan tentang pengangkatan anak yang memadai.

3. Diusahakan ada penyatuan istilah pengangkatan anak dan meniadakan istilah-istilah lain.

4. Pengangkatan anak jangan memutuskan hubungan antara anak yang diangkat dengan orang tua kandung.

5. Hubungan harta kekayaan/kehartabendaan antara anak yang diangkat dengan orang tua angkat dianjurkan agar dalam hubungan hibah dan wasiat

6. Pengangkatan anak yang terdapat dalam hukum adat hendaknya diusahakan agar tidak bertentangan dengan hukum Islam.

7. Pengangkatan anak oleh warga negara asing supaya diadakan pembatasan yang lebih ketat.

8. Tidak dibenarkan pengangkatan anak oleh orang tua yang berlainan agama. ${ }^{14}$ Majelis Ulama Indonesia (MUI) dalam Rapat Kerja Nasional Majelis Ulama Indonesia tahun 1984 yang berlangsung pada Jumadil Akhir 1405 H/Maret 1984 memfatwakan tentang adopsi sebagai :

1. Islam mengakui keturunan (nasab) yang sah, ialah anak yang lahir dari perkawinan (pernikahan).

2. Mengangkat (adopsi) dengan pengertian anak tersebut putus hubungan keturunan (nasab) dengan ayah dan ibu kandung bertentangan dengan syariat Islam.

3. Adapun pengangkatan anak dengan tidak mengubah status nasab dan agama dilakukan atas rasa tanggung jawab sosial untuk memelihara, mengasuh dan mendidik dengan penuh kasih sayang, seperti anak sendiri merupakan perbuatan yang terpuji dan termasuk amal saleh yang dilanjutkan oleh agama Islam.

\footnotetext{
${ }^{14}$ R. Soeroso, Perbandingan Hukum Perdata (Cet. VIII; Jakarta: Sinar Grafika, 2010), h. 199.
} 
4. Pengangkatan anak Indonesia oleh Warga Negara Asing selain bertentangan dengan UUD 1945 Pasal 34 juga merendahkan martabat bangsa. ${ }^{15}$

Menurut Pasal 171 huruf h Kompilasi Hukum Islam yang sejalan dengan Pasal 39 ayat 2 Undang-undang Nomor 23 Tahun 2002 tentang Perlindungan Anak yang menegaskan bahwa "Pengangkatan anak sebagaimana dimaksud dalam ayat 1 tidak memutuskan hubungan darah antara anak yang diangkat dan orang tua kandungnya".

\section{Pengangkatan Anak/Adopsi dalam Sistem Hukum di Indonesia}

Pada Tanggal 7 April 1979, Mahkamah Agung mengeluarkan Surat Edaran Mahkamah Agung No. 2 Tahun 1979 mengenai Pengangkatan Anak yang disempurnakan oleh Surat Edaran Mahkamah Agung No. 6 Tahun 1983 yang menjadi dasar hukum internal bagi para hakim dalam memutuskan segala bentuk pengajuan permohonan adopsi atau pengangkatan anak di Indonesia. Menurut SEMA No. 6 Tahun 1983 tentang Penyempurnaan SEMA No. 2 Tahun 1979 mengenai Tata cara Pengangkatan Anak ditegaskan bahwa penetapan dan keputusan pengadilan merupakan syarat bagi sahnya pengangkatan anak. Menurut SEMA No. 3 Tahun 2005 tentang Pengangkatan Anak yang berisi peringatan Mahkamah Agung kepada para hakim yang memutuskan permohonan adopsi terutama intercountry adoption (adopsi antar negara) untuk selalu memperhatikan ketentuan-ketentuan yang terdapat dalam SEMA No. 6 Tahun 1983 untuk melindungi hak anak Indonesia yang akan diadopsi dan berkaitan dengan lembaga adopsi atau pengangkatan anak terhadap korban bencana alam gempa bumi dan tsunami di Nanggroe Aceh Darussalam. SEMA No. 2 Tahun 2009 tentang kewajiban melengkapi permohonan pengangkatan anak dengan akta kelahiran.

Selain beberapa Surat Edaran Mahkamah Agung Republik Indonesia sebagaimana dijelaskan sebelumnya yang digunakan dalam internal pengadilan bagi para hakim dalam memutuskan sebuah permohonan adopsi terdapat juga berbagai peraturan perundangundangan dalam tata urutan perundang-undangan di Indonesia yang menjelaskan mengenai lembaga adopsi atau pengangkatan anak di Indonesia diantaranya :

1. Undang-undang No. 4 Tahun 1979 tentang Kesejahteraan Anak, sebagaimana dijelaskan dalam Pasal 12 bahwa pengangkatan anak dilaksanakan dengan mengutamakan kepentingan kesejahteraan anak yang dilakukan berdasarkan adat dan

\footnotetext{
${ }^{15}$ Abdul Wahab Abd. Muhaimin, Kajian Islam Aktual (Cet. I; Jakarta: Gaung Persada Press), h. 152153.
} 
kebiasaan dan diluar adat dan kebiasaan dilaksanakan berdasarkan peraturan perundang-undangan.

2. Undang-undang No. 23 Tahun 2002 tentang Perlindungan Anak, sebagaimana terdapat dalam Bab VIII Bagian Kedua Pasal 39-41 mengenai pengangkatan anak yang menjelaskan bahwa pengangkatan anak dilakukan untuk kepentingan terbaik bagi anak sebagaimana juga dijelaskan dalam UU Kesejahteraan Anak, pengangkatan anak tidak memutuskan hubungan darah antara anak yang diangkat dengan orang tua kandung, mengenai agama dari anak yang akan diangkat, mengenai pengangkatan anak oleh WNA haruslah merupakan suatu upaya terakhir, mengenai kewajiban pemberitahuan asal usul anak angkat oleh orang tua angkat dan mengenai hal-hal lain yang kemudian akan diatur oleh Peraturan Pemerintah.

3. Undang-undang No. 12 Tahun 2006 tentang Kewarganegaraan Republik Indonesia dimana dijelaskan dalam Pasal 5 ayat (2) jo Pasal 6 UU ini mengenai kewarganegaraan dari anak WNI yang diadopsi oleh WNA.

4. Peraturan Pemerintah Republik Indonesia No. 54 Tahun 2007 tentang Pelaksanaan Pengangkatan Anak.

5. Peraturan Menteri Sosial Republik Indonesia No. 110/HUK/ 2009 tentang Persyaratan Pengangkatan Anak. ${ }^{16}$

Pasal 12 PP No. 54 Tahun 2007, syarat-syarat pengangkatan anak di Indonesia, meliputi:

1. Syarat anak yang akan diangkat, meliputi:

a. Belum berusia 18 (delapan belas) tahun

b. Merupakan anak terlantar atau ditelantarkan

c. Berada dalam asuhan keluarga atau dalam lembaga pengasuhan anak

d. Memerlukan perlindungan khusus.

2. Usia anak angkat sebagaimana dimaksud pada ayat (1) huruf a meliputi:

a. Anak belum berusia 6 (enam) tahun merupakan prioritas utama

b. Anak berusia 6 (enam) tahun sampai dengan belum berusia 12 (dua belas) tahun sepanjang ada alasan mendesak

\footnotetext{
${ }^{16}$ R. Soeroso, Perbandingan Hukum Perdata (Cet. VIII; Jakarta: Sinar Grafika, 2010), h. 201.
} 
c. Anak berusia 12 (dua belas) tahun sampai dengan belum berusia 18 (delapan belas) tahun sepanjang anak memerlukan perlindungan khusus.

3. Calon orang tua angkat harus memenuhi syarat-syarat:

a. Sehat jasmani dan rohani

b. Berumur paling rendah 30 (tiga puluh) tahun dan paling tinggi 55 (lima puluh lima) tahun.

c. Beragama sama dengan agama calon anak angkat

d. Berkelakuan baik dan tidak pernah dihukum karena melakukan tindak kejahatan

e. Berstatus menikah paling singkat 5 (lima) tahun

f. Bukan merupakan pasangan sejenis

g. Tidak atau belum mempunyai anak atau hanya memiliki satu orang anak

h. Mampu ekonomi dan sosial

i. Memperoleh persetujuan anak dan izin tertulis orang tua atau wali anak

j. Membuat pernyataan tertulis bahwa pengangkatan anak adalah demi kepentingan terbaik bagi anak, kesejahteraan dan perlindungan anak

k. Adanya laporan sosial dari pekerja sosial setempat

1. Telah mengasuh calon anak angkat paling singkat 6 (enam) bulan sejak izin pengasuhan diberikan

m. Memperoleh izin menteri dan/atau kepala instansi sosial.

Undang-undang RI Nomor 23 Tahun 2002 tentang Pengangkatan Anak tidak menentukan norma hukum tentang pengadilan mana yang berwenang untuk menerima (mengadili) perkara permohonan pengangkatan anak.

Menurut Undang-undang RI Nomor 3 Tahun 2006 tentang Perubahan atas Undangundang Nomor 7 Tahun 1989 tentang Peradilan Agama mengakibatkan Pengadilan Agama bertugas dan berwenang memeriksa, memutus, dan menyelesaikan perkara di tingkat pertama antara orang-orang yang beragama Islam di bidang perkawinan, salah satunya yaitu penetapan asal-usul seorang anak dan penetapan pengangkatan anak berdasarkan hukum Islam.

Apabila pihak pemohon dan anak beragama Islam maka Permohonan tersebut disebutkan dengan berbagai macam isi petitum, yaitu:

1. Apabila pengangkatan anak dilakukan antara Warga Negara Indonesia maka isi petitum/permintaan permohonan yang pokoknya cukup dengan "Agar si anak dari A ditetapkan sebagai anak angkat dari B", atau "Agar penangkatan anak yang telah 
dilakukan oleh Pemohon A terhadap anak B yang bernama C dinyatakan sah.” Tanpa ditambahkan tuntutan lainnya, seperti "Agar ditetapkan anak bernama A tersebut, ditetapkan sebagai ahli waris dari B."

2. Apabila pengangkatan anak dilakukan antara anak Warga Negara Asing oleh orang tua angkat Warga Negara Indonesia, maka isi petitum/permintaan permohonan yang pokoknya adalah cukup dengan "Agar si anak dari B ditetapkan sebagai anak angkat dari C," atau "Agar pengangkatan anak yang telah dilakukan oleh Pemohon C terhadap anak B yang bernama A dinyatakan sah," tanpa ditambah tuntutan lain seperti, "Agar ditetapkan anak bernama A tersebut ditetapkan sebagai ahli waris dari C," atau agar anak bernama A tersebut ditetapkan berwarganegaraan RI mengikuti status kewarganegaraan ayah angkatnya yang bernama $\mathrm{C}$ tersebut."

3. Apabila permohonan/pengangkatan anak Warga Negara Indonesia oleh orang tua angkat Warga Negara Asing, maka petitum/permohonan yang pokok adalah "Agar si anak dari B ditetapkan sebagai anak angkat dari C," atau "Agar pengangkatan anak yang telah dilakukan oleh Pemohon C terhadap anak B yang bernama A dinyatakan sah," tanpa ditambah tuntutan lain seperti: "Agar ditetapkan anak bernama $\mathrm{S}$ tersebut ditetapkan sebagai ahli waris dari C," atau "Agar anak bernama A tersebut ditetapkan berkewarganegaraan RI mengikuti status kewarganegaraan anak angkat yang bernama C tersebut."

Setelah memenuhi seluruh syarat-syarat seperti yang telah disebutkan maka untuk pengesahan (legalisasi) adopsi selanjutnya perlu ditempuh dua prosedur sebagai berikut:

4. Prosedur Awal

a. Pemohon mengunjungi Dinas Sosial setempat dan menjelaskan keinginan untuk melakukan adopsi dan pihak Dinas Sosial tersebut akan memberitahu syarat-syarat administratif yang harus dipenuhi disertai juga contoh surat-suratnya termasuk Surat Permohonan Izin Adopsi yang ditujukan kepada Kepala Dinas Sosial setempat dan lainnya seperti: Foto copy KTP dari orang tua kandung/wali yang sah/kerabat calon anak angkat, foto copy KTP calon orang tua angkat, akta kelahiran calon anak angkat.

b. Apabila berkas telah dilengkapi maka diserahkan ke Dinas sosial. Kemudian, pemohon diminta menunggu adanya Tim dari Dinas Sosial yang disebut dengan Tim PIPA 
(Pertimbangan Perizinan Pengangkatan Anak) yang akan melakukan peninjauan langsung terhadap kehidupan calon orang tua angkat dan anak dengan melakukan home visit.

c. alon orang tua angkat (pemohon) secara langsung (tidak bisa diwakili) diminta hadir ke kantor Dinas Sosial untuk mengikuti interview langsung dengan Tim PIPA untuk menegaskan kembali komitmen calon orang tua angkat untuk adopsi anak setelah dilakukan home visit oleh Dinas Sosial.

d. calon orang tua (pemohon) harus menunggu Surat Rekomendasi Pengangkatan Anak dari Kepala Dinas Sosial setempat.

2. Prosedur lanjutan :

a. Pemohon mengajukan Permohonan Pengangkatan Anak ke Pengadilan Negeri (khusus di Aceh bagi yang beragama Islam diajukan ke Mahkamah Syar'iyah) dengan melampirkan Surat Rekomendasi tersebut disertai pembayaran biaya perkara setelah mendapat Surat Rekomendasi Pengangkatan Anak dari Dinas Sosial

b. Pemohon akan dipanggil untuk mengikuti sidang pemeriksaan oleh hakim yang ditunjuk Ketua Pengadilan untuk menangani perkara permohonan. Pada proses pemeriksaan tersebut, pemohon diminta untuk menghadirkan 2 orang saksi yang akan menegaskan kapabilitas (kemampuan) calon orang tua angkat untuk mengadopsi anak.

c. Diperkirakan akan ada beberapa kali sidang. Apabila pada sidang pertama ada beberapa prosedur administrasi atau kehadiran saksi belum dipenuhi maka dipenuhi pada siding berikutnya

d. Sidang terakhir yaitu putusan berupa penetapan atas permohonan adopsi sahabat yang akan dibacakan oleh hakim dalam siding.

e. Apabila permohonan disetujui maka pemohon harus mengambil salinan putusan penetapan pada pengadilan yang bersangkutan setelah sidang selesai pada petugas yang bersangkutan (tidak diberikan dalam proses sidang), putusan tersebut merupakan bukti tertulis sahnya adopsi yang pemohon lakukan.

Berdasarkan peraturan perundang-undangan yang berlaku di Indonesia tersebut dapat diketahui bahwa Indonesia telah menjamin pemberian hak anak adopsi untuk mengetahui asalusulnya sebagaimana tercantum dalam pasal-pasal berikut:

1. Pasal 2 ayat (2) Peraturan Menteri Sosial No. 110 Tahun 2009 tentang Persyaratan Pengangkatan Anak yang berbunyi sebagai berikut: 
(2) Selain prinsip sebagaimana dimaksud pada ayat (1) orang tua angkat wajib memberitahukan kepada anak angkat mengenai asal usulnya dan orang tua kandung dengan memperhatikan kesiapan mental anak.

2. Pasal 6 Peraturan Pemerintah No. 54 Tahun 2007 tentang Pelaksanaan Pengangkatan Anak yang berbunyi sebagai berikut:

a. Orang tua angkat wajib memberitahukan kepada anak angkatnya mengenai asalusulnya dan orang tua kandungnya.

b. Pemberitahuan asal-usul dan orang tua kandung sebagaimana dimaksud pada ayat (1) dilakukan dengan memperhatikan kesiapan anak yang bersangkutan. ${ }^{17}$

Anak angkat berhak untuk mengetahui asal-usulnya dan dijamin dalam hukum yang berlaku di Indonesia. Apakah orang tua angkat memberitahukan asal-usul anak yang mereka adopsi sesuai dengan kewajiban yang mereka miliki berdasarkan peraturan perundangundangan yang berlaku di Indonesia tidaklah mudah karena hal ini sudah masuk dalam ranah pribadi yang bersifat sangat personal. Namun, untuk mengetahui mengenai penerapan dan aplikasi dari hak tersebut dapat dilihat dari adopsi yang dilakukan oleh public figure di Indonesia, salah satunya adalah artis Yuni Shara. Yuni Shara dan mantan suaminya sebelum memiliki anak kandung dari perkawinan mereka telah mengadopsi seorang bayi laki - laki yang mereka beri nama Cavin Obrient Salomon yang telah berusia 3 tahun ketika Yuni melahirkan anak kandungnya. Meskipun pada akhirnya Yuni Shara dan suaminya memiliki anak kandung mereka sendiri, namun mereka sepakat bahwa bayi yang baru lahir itu merupakan anak keduanya. "Bagaimanapun ini adalah anak kedua saya. Anak pertama ya tetap Calvin. Kami tidak akan membeda-bedakan perlakuan dan kasih sayang pada Cavin dan anak kandung kami sendiri nanti. Status Cavin pun tidak akan kami tutup-tutupi. Cavin pun tahu siapa orang ctua yang sebenarnya," terang Yuni dan suaminya

\footnotetext{
${ }^{17}$ R. Soeroso, Perbandingan Hukum Perdata (Cet. VIII; Jakarta: Sinar Grafika, 2010), h. 210.
} 


\section{PENUTUP}

Mengenai pengangkatan anak/adopsi belum ada persamaan atau kesatuan arti. Namun, secara garis besar adposi dapat dibagi ke dalam dua pengertian, yaitu:

1. Adopsi dalam arti luas yakni pengangkatan anak/ adopsi orang lain sedemikian rupa sehingga antara anak yang diangkat dengan orang tua angkat timbul hubungan antara anak angkat sebagai anak kandung dan orang tua angkat kandung.

2. Adopsi dalam arti terbatas yakni pengangkatan anak/ adopsi orang lain yang memiliki hubungan terbatas pada hubungan sosial yaitu sebagai anak angkat dan orang tua angkat.

Sejak zaman dahulu, pengangkatan anak telah dilakukan dengan cara dan motivasi yang berbeda-beda sejalan dengan sistem hukum dan perasaan hukum yang hidup serta berkembang di dalam masyarakat yang bersangkutan. Tujuan dan pelaksanaan dari adopsi

bermacam-macam, ditinjau dari hukum Islam serta penerapannya pada sistem hukum di Indonesia 


\section{DAFTAR PUSTAKA}

Departemen Agama RI. Al-Qur'an dan Terjemahnya. Jakarta: CV. Pustaka Agung Harapan, 2006.

Fachrudin, Mohammad Fuad. Masalah Anak Dalam Hukum Islam. Jakarta: CV. Pedoman Ilmu Jaya, 1993.

Muhaimin, Abdul Wahab Abd. Kajian Islam Aktual. Cet. I; Jakarta: Gaung Persada Press.

Zaini, Muderi, Adopsi (Suatu Tinjauan Dari Tiga Sistem Hukum). Jakarta: Sinar Grafika, 2012.

Meliala, Djaja S. Pengangkatan Anak (Adopsi) di Indonesia. Bandung: Tarsito, 1982.

Soeroso, R. Perbandingan Hukum Perdata. Cet. VIII; Jakarta: Sinar Grafika, 2010.

Al-Barry, Zakaria Ahmad. Ahkamu al-Audud fi al-Islam. Jakarta: Bulan Bintang, 1977.

Soimin, Soedharyo. Hukum Orang \& Keluarga. Cet. III; Jakarta: Sinar Grafika, 2010.

Martosedono, Amir. Tanya Jawab Pengangkatan Anak \& Masalahanya. Semarang: Dahara Prize, 1997.

Satrio, J. Hukum Keluarga tentang Kedudukan Anak dalam Undang-undang., Bandung: PT. Citra Bakti, 2000.

Yanggo, Chuzaimah T. Problematika Hukum Islam Kontemporer. Jakarta: Pustaka Firdaus, 1994), h. 132.

Syaltut, Mahmud. Al-Fatawa. Mesir: Dar al-Syuruq, 1980. 